\title{
PIGMEN KLOROFIL PADA ALGA Caulerpa sp. DIKEPULAUAN KEI
}

\author{
Cenny Putnarubun"1, Riris Yuli Valentine ${ }^{2}$ \\ 1 Jurusan Teknologi Hasil Perikanan, Politeknik Perikanan Negeri Tual, \\ Jl. Raya Langgur-Sathean KM-6, Maluku Tenggara 97611, Maluku, Indonesia \\ 2 Program studi Teknik Budidaya Perikanan, Politeknik Kelautan dan Perikanan Kupang, \\ Kupang Barat, Nusa Tenggara Timur 85351, Nusa Tennggara Timur, Indonesia \\ Koresponden :*cennyputri@gmail.com; ririssinaga.kkp@gmail.com \\ (Diterima 19-05-2020; Direvisi 31-05-2020; Dipublikasi 18-06-2020)
}

\begin{abstract}
ABSTRAK
Salah satu tumbuhan yang berklorofil dan tumbuhnya berupa thalus adalah makroalga, alga mampu hidup pada perairan, dan meiliki pertumbuhan yang sangat cepat dengan berfotosintetis. Penelitian ini dilakukan untuk mengetahui kandungan pigmen alga Caulerpa sp. di kepulauan Kei. Metode penelitian pigmen alga dengan metode kolom kromotografi. Hasil yang diperoleh untuk memisahkan pigmen klorofil pada alga Caulerpa sp dengan menggunakan kromotografi kolom adalah b-karoten, xantofil, karatenoin, klorofil a dan klorofil b.
\end{abstract}

Kata Kunci : Analisis; Alga; Caulerpa sp.; Klorofil; Pigmen.

\section{Chlorophyll Pigment in Algae Caulerpa sp. on the Kei Islands}

\section{ABSTRACT}

One of the plants that has chloropyll and macroalgae is growth, algae are able to live the waters, and have very fast growth with photosynthesis. This research was conducted to determine the pigment content of Caulerpa sp. algae in the Kei Islands. Algae pigment research method using column 86hromatography method. The results obtained to separate the chlorophyll pigments in algae Caulerpa sp. using colomn chromatography are b-carotene, xanthophyll, caratenoin, chlorophyll a and chlorophyll b.

Keywords : Analysis; Algae; Caulerpa sp.; Chlorophyll; Pigment. 


\section{PENDAHULUAN}

Alga adalah sekelompok organisme yang bervariasi meliputi bentuk, ukuran, warna (pigmen) dan komposisi senyawa kimia lainnya (Leibo et al. 2016). Makroalga atau dikenal dengan rumput laut merupakan kekayaan hayati laut yang banyak tersebar di perairan Indonesia, baik tumbuh secara alami maupun hasil budidaya. Alga telah lama dimanfaatkan oleh masyarakat sebagai obat, bahan pangan maupun kosmetik. Alga Indonesia telah diteliti mengandung antioksidan yang tinggi dalam menangkal radikal bebas (Firdaus 2003; Diachanty et al. 2017; Nufus et al. 2017; Gazali et al. 2018) dan dapat meningkatkan sistem imun (Subaryono et al. 2017). Komoditi alga telah diteliti mengandung komponen bioaktif di antaranya fenol (Machu et al. 2015; Zakaria et al. 2017), flavonoid (Elmegeed et al. 2014).

Klorofil dan karotenoid (Rohani-Ghadikolaei et al. 2012; Pangestuti dan Kim 2011) dan polisakarida sulfat (Barahona et al. 2014). Klorofil dan karotenoid merupakan pigmen alami yang tersebar pada semua jenis alga baik Phaeophyceae, Rhodophyceae dan Chlorophyceae dengan komposisi yang bervariasi (Chen et al. 2017; Bocanegara et al. 2009; Holdt dan Kraan 2011). Alga hijau (Chlorophyceae) merupakan jenis alga yang memiliki kandungan klorofil paling tinggi (Haryatfrehni et al. 2015).
Pigmen klorofil dan karotenoid telah diteliti mempunyai efek biologis untuk meningkatkan kesehatan, diantaranya antioksidan, antiinflamasi maupun antikanker (Pangestuti dan Kim 2011; Prangdimurti et al. 2006). Salah satu alga potensial adalah alga hijau Caulerpa sp. yang tumbuh secara alami dan hanya terdapat disebagian kecil perairan tertentu dilndonesia salah satunya Propinsi Maluku, namun hanya di kepulauan Kei.

Alga hijau Caulerpa sp. dikenal oleh masyarakat Kei sebagai Lat (nama lokal) atau anggur laut, alga ini dikonsumsi sebagai sayuran atau lalapan mentah oleh masyarakat Kei. Alga Caulerpa sp. tumbuh secara alami dan tidak mengenal musim.

Tujuan penelitian ini adalah mengetahui kandungan pigmen klorofil pada Alga Hijau Caulerpa sp. dengan metode kromotografi lapis tipis (KLT).

\section{METODE PENELITIAN}

\section{Waktu dan tempat}

Penelitian analisis pigmen klorofil Alga Caulerpa sp. dilakukan pada Laboratorium Dasar Politeknik Perikanan Negeri Tual. Titik pengambilan sampel alga Caulerpa sp. di Kepulauan Kei. Gambar Caulerpa sp. Dapat dilihat pada Gambar 1. 


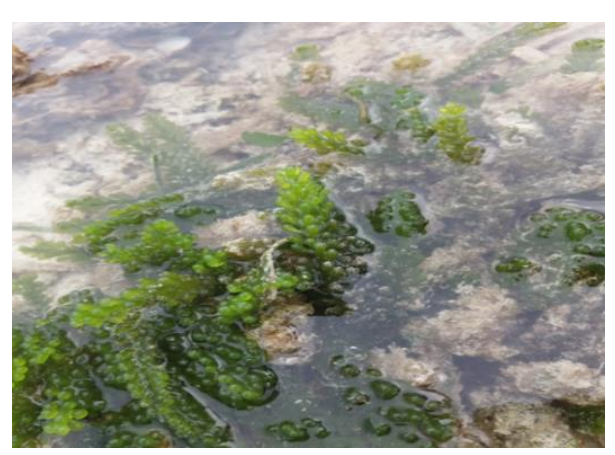

Gambar 1. Alga Caulerpa sp

\section{Alat dan bahan}

Alat yang digunakan dalam penelitian ini meliputi lumping, alu, gelas ukur, tabung reaksi, pipet tetes, statif, buret, erlemeyer, sentrifugasi, pipet volum, kolom, magnetic stirer, hot plate, almonium foil ,pisau, dan vial.

Bahan yang digunakan dalam penelitian ini meliputi silica gel, aseton, n-heksana, kapas, dan alga caulerpa sp.

\section{Prosedur penelitian}

Penelitian ini dilakukan dengan menggunakan metode penelitian deskriptif. Sampel dianalisis di laboratorium, data yang diperoleh adalah data kualitatif.

\section{Pengambilan dan preparasi sampel}

Sampel alga caulerpa sp. di ambil dilaut Kei, selanjutnya dicuci dengan air mengalir sampai bersih, dengan tujuan membersihkan pasir, karang dan kotoran yang menempel pada alga Caulerpa sp.

\section{Proses ekstraksi}

Sampel yang telah dibersihkan, dilakukan proses ekstraksi. Sebelum dilakukan proses ekstraksi alga caulerpa sp diambil dan ditimbang dengan berat $50 \mathrm{gr}$, kemudian sampel dipotong kecil-kecil dengan menggunakan pisau. Selanjutnya dilakukan penggerusan dengan menggunakan lumpang dan alu. Selama penggerusan ditambahkan aseton sebanyak $50 \mathrm{ml}$. Penggerusan dilakukan secara terus menerus hingga larutan berubah warna dengan tujuan untuk mendapatkan ekstrak klorofil secara maksimal. Sampel alga dapat dilihat pada gambar 2.

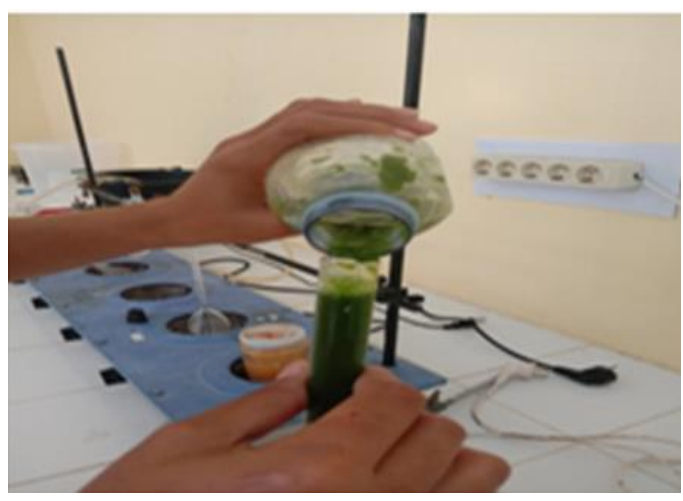

Gambar 2. Sampel ekstrak alga Caulerpa sp.

\section{Proses karakterisasi pigmen klorofil dengan kolom}

Hasil ekstraksi alga caulerpa sp. kemudian disentrifugasi dengan menggunakan sentrifugus dengan kecepanan $3000 \mathrm{rpm}$, sampel sentrifugasi alga caulerpa dapat dilihat pada Gambar 3. 


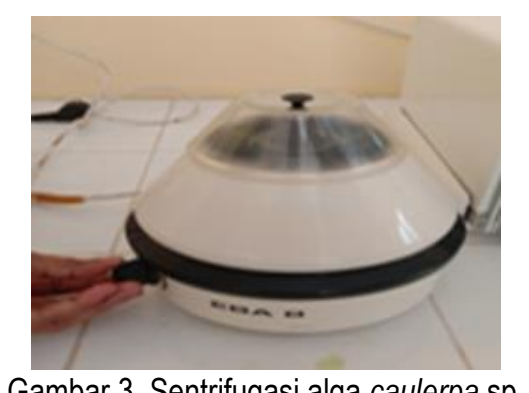

Gambar 3. Sentrifugasi alga caulerpa sp.

Hasil sentrifugasi berupa supernatan diambil dan dimasukan ke dalam tabung reaksi/erlemeyer untuk dilakukan pencampuran reaksi dengan perbandingan 4:1, 3:2, 2:3, 1:4 menggunakan larutan aseton dan $\mathrm{n}$-heksan..

\section{Penyiapan kolom dan fase diam}

Tahap pertama menyiapkan kolom untuk kromatografi, masukkan kapas dan kertas saring pada bagian kolom dan kran kolom ditutup. Tahap kedua tuangkan cairan fase gerak sampai setengah bagian kolom, masukkan fase diam yang akan digunakan sampai jumlah yang dikehendaki. Tahap ketiga keluarkan cairan fase gerak sampai $1 \mathrm{~cm}$ diatas permukaan fase diam. Amati dengan baik. Perhatikan jangan sampai ada gelembung udara dalam fase diam. Kolom siap digunakan.

Selanjutnya secara perlahan buka kran kolom sehingga eluen akan mengalir keluar, dan tatat waktu pertama setelah penetesan fase gerak. Lalu masukan masukan sampel alga Caulerpa sp. ke dalam kolom sesuai urutan perbandingan larutan yakni 4:1, 3:2, 2:3, 1:4, serta amati perubahan pigmen warna yang melewati kolom tadi, kromotografi. Fraksi yang keluar http://ejurnal.ung.ac.id/index.php/jfpj/issue/archive ditampung tiap $2 \mathrm{~mL}$, catat pada menit beberapa tetesan atau fraksi yang berisi analit pertama mulai keluar (menit pertama dan terakhir untuk suatu analit yang sama). Demikian seterusnya untuk analit berikutnya. Penambahan fase gerak jangan sampai terlambat yaitu jangan sampai cairan fase gerak diatas fase diam habis. Contoh kolom pada gambar 4 .

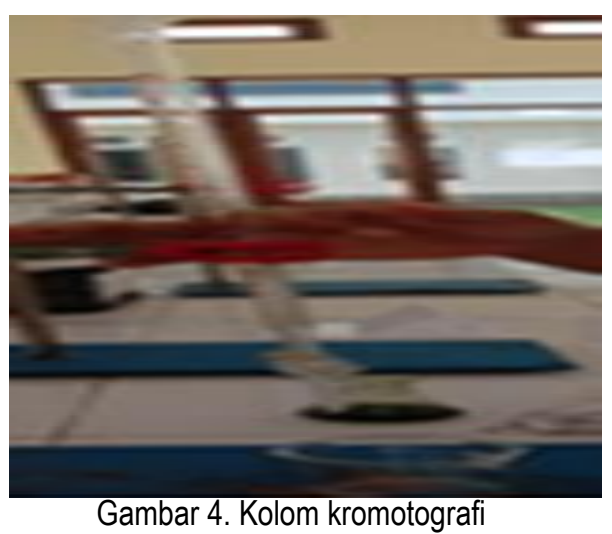

\section{HASIL DAN PEMBAHASAN}

\section{Hasil analisis pigmen klorofil alga Caulerpa sp.}

Alga telah diteliti mengandung komponen bioaktif di antaranya fenol (Machu et al. 2015; Zakaria et al. 2017), flavonoid (Elmegeed et al. 2014), klorofil, karotenoid (Rohani-Ghadikolaei et al. 2012; Pangestuti dan Kim 2011) dan polisakarida sulfat (Barahona et al. 2014). Klorofil dan karotenoid merupakan pigmen alami yang tersebar pada semua jenis rumput laut baik Phaeophyceae, Rhodophyceae dan Chlorophyceae dengan komposisi yang bervariasi (Chen et al. 2017;Bocanegara et al. 2009; Holdt dan Kraan 2011). Hasil penelitian diperoleh 
pigmen warna dari hasil kromotografi kolom alga caulerpa sp seperti Tabel 1.

Tabel 1. Pigmen warna caulerpa sp

\begin{tabular}{lcll}
\hline Sampel & Fraksi & \multicolumn{1}{c}{ Warna } & \multicolumn{1}{c}{ Pigmen } \\
\hline \multirow{3}{*}{ Caulerpa } & 1 & Kuning tua & b-Karoten \\
sp & 2 & Kuning muda & Xantofil \\
& 3 & Kuning & Karatenoin \\
& 4 & Hijau kebiruan & Klorofil a \\
& 5 & Hijau kenuningan & Klorofil b \\
\hline
\end{tabular}

Hasil kromotografi fraksi 1 warna yang keluar menunjukan warna kuning tua, maka pigmen yang dihasilkan adalah B-karoten. Beta-karoten pada setiap RC mempunyai fungsi proteksi, dan karotenoid pada sisi periferal LHC PSII berfungsi sebagai pemanen cahaya. Beta-karoten terdapat pada kompleks reaction center $(\mathrm{RC})$ dan lightharvesting complex (LHC) fotosistem I (PSI) serta pada RC dan inti LHC fotosistem II (PS II).

Zeaxantin yang terdapat dalam LHC PSI pada beberapa algae merah. Pada bagian periferal LHC PS II, terikat berbagai jenis karotenoid sesuai dengan kelas algae. Karotenoid utama yang ditemukan ialah alloxantin (Cryptophyta); fukoxantin (Chrysophyceae, Raphidophyceae, Bacillariophyceae, Phaeophyceae, serta (Haptophyceae); diadinoxantin dan vaucheriaxantin (Xantophyceae); violaxantin dan vaucheriaxantin (Eustigmatophyceae); peridinin (Dinophyta); diadinoxantin (Euglenophyta); siphonaxantin (Chlorophyceae dan Ulvophyceae), serta lutein, violaxantin dan 9'-cis neoxantin (tumbuhan darat) (Durnrof, 2003; Macpherson \& Hiller, 2003; Neilson \& Durnford, 2010). Fraksi ke 2 warna kuning muda menunjukan pigmen xantofil. Xantofil merupakan karotenoid yang mengandung gugus hidroksil. Xantofilumum biasanya berupa monohidroksikarotena (misalnya lutein, rubixantin), dihidroksikarotena (zeaxantin), atau dihidroksiepoksikarotena (violaxantin).

Fraksi ke 3 warna kuning menunjukkan pigmen karatenoid. Fraksi 4 warna hijau kebiruan menunjukkan pigmen klorofil a dan fraksi 5 warna hijau kekuningan menunjukkan pigmen klorofil $b$. karatenoid, klorofil $a$, dan klorofil $b$ memiliki fungsi yang sangat penting dalam kehidupan. Pembentukan warna pigmen dengan kromotografi kolom dapat dilihat pada Gambar 5.a dan b.

Klorofil dan karotenoid berikatan dengan peptida, membentuk pigmen-protein kompleks pada membran tilakoid. 5 jenis pigmen protein kompleks pada algae telah diisolasi serta dianalisis komposisi pigmennya (Durnrof, 2003; Macpherson \& Hiller, 2003; Neilson \& Durnford, 2010). Pada fotosintesis, karotenoid mempunyai peranan penting yaitu sebagai pigmen aksesoris pemanen cahaya serta sebagai triplet quencher untuk melindungi komponen fotosintesis dari kerusakan fotooksidatif (Krinsky, 1968; Goodwin, 1976; Cogdell, 1987). 


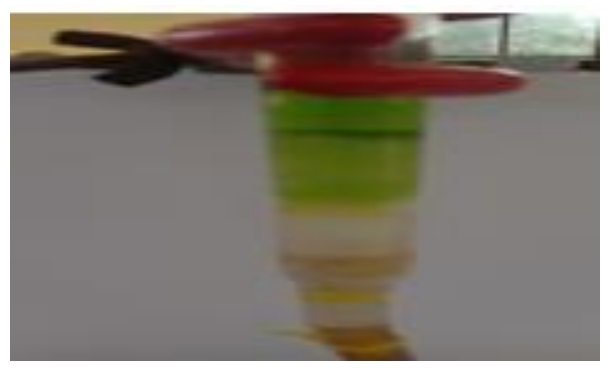

(a)

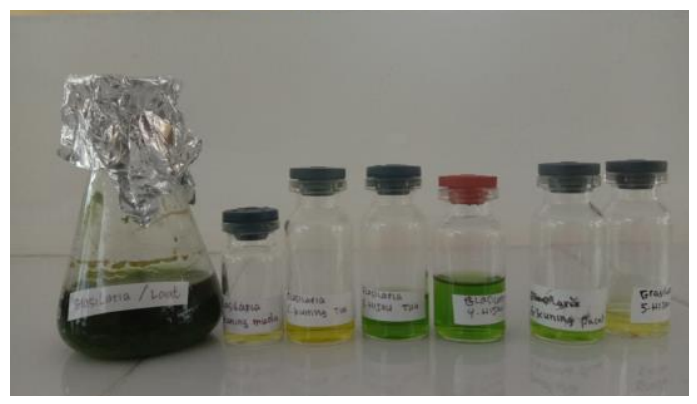

(b)

Gambar 5. (a) Kromotografi Kolom yang menunjukkan warna pigmen; (b) vial penampung fraksi $1,2,3,4$, dan 5 pigmen warna caulerpa $\mathrm{sp}$.

Mekanisme fotoproteksi karotenoid meliputi quenching chlorophyll triplet state sehingga mencegah pembentukan oksigen singlet yang dapat mengoksidasi klorofil. Selain itu karotenoid juga mampu mencegah pembentukan oksigen singlet secara langsung. Karotenoid dalam LHC berfungsi untuk menyerap energi pada panjang gelombang yang tidak efisien diserap oleh klorofil. Energi diserap oleh karotenoid dan disalurkan ke klorofil hingga akhirnya sampai pada pusat reaksi. Efisiensi transfer energi dari tahap singlet excited karotenoid ke tahap singlet excited klorofil pada LHC tergantung pada struktur dan eksitasi energi karotenoid serta jarak dan posisinya terhadap klorofil (Bacon, 2001).
Singlet state karotenoid mempunyai energi lebih tinggi sedangkan triplet state karotenoid mempunyai energi yang lebih rendah dibandingkan tahapan energi pada klorofil, kondisi tersebut mendukung peran karotenoid sebagai fotoprotekto dan pigmen aksesoris pemanen cahaya (Cogdell, 1987). Pemisahan pigmen dengan kromatografi kolom menggunakan larutan aseton dan heksana 4:1, 3:2, 2:3, 1:4 memperoleh 5 lapisan pigmen yaitu pigmen b-karoten, karatenoin, klorofil a, klorofil b, dan xantofil. Dengan warna karoten berwarna kuning, klorofil a berwarna hijau tua, klorofil b berwarna hijau muda, dan xiantofil yang berwarna kuning muda. Data ini sesuai dengan deskripsi yang menyatakan bahwa klorofil a berwarna hijau biru, klorofil $b$ berwarna hijau kuning dan karatenoin berwarna kuning orange. Karotenoid dibedakan menjadi dua golongan utama yaitu: karotenoit polar (xantofil) dan karotenoid non polar (karoten). Perbedaan warna ini juga berpengaruh dari serapan yang bervariasi dan juga panjang dari nanometer yang dihasilkan dari masing-masing pigmen.

\section{KESIMPULAN}

Pigmen warna yang berhasil diisolasi menggunakan kromatografi kolom pada alga caulerpa sp adalah b-karoten, xantofil, karatenoin, klorofil a dan klorofil b. 


\section{DAFTAR PUSTAKA}

Bacon, K. 2001 Photosynthesis: Photobiochemistry and Photobiophysics. Kluwer Academics Publisher, Netherland.

Bocanegara, A., Bastida, S., Benedi, J., Rodenas, S., Sanchez-Muniz, F.J. 2009. Characteristics and nutritional and cardiovascular-health properties of seaweeds. Journal Medicine Food. 12(2): 236-258.

Barahona, T., Encinas, M.V., Imarai, M., Mansilla, A., Matsuhiro, B., Torres, R., Valenzuela, B. 2014. Bioactive polysaccharides from marine algae. Journal Bioactive Carbohydrate and Dietary Fibre. 4(2): 125138.

Chen, K., Ríos, J.J., Perez-Galvez, A., Roca, M. 2017. Comprehensive chlorophyll composition in the main edible seaweeds. Food Chemistry. 228: 625-633.

Cogdell RJ, Frank HA. 1987. Biochim. Biophys. Acta. 895:63-79.

Diachanty S, Nurjanah, Abdullah A. 2017. Aktivitas antioksidan berbagai jenis rumput laut coklat dari Perairan Kepulauan Seribu. Jurnal Pengolahan Hasil Perikanan Indonesia. 20(2): 305-318.

Durnford, D.G. 2003. Structure and regulation of algal light-harvesting complex genes. In Photosynthesis in Algae; Larkum, A.W.D., Douglas, S.E., Raven, J.A., Eds.; Kluwer: Dordrecht, The Netherlands.

Elmegeed, D.F.A., Ghareeb, D.A., Elsayed, M., El-Saadan,i M. 2014. Phytochemical constituents and bioscreening activities of green algae Ulva lactuca. International Journal of Agricultural Policy and Research. 2(11): 373-378.

http://ejurnal.ung.ac.id/index.php/jfpj/issue/archive
Firdaus, M. 2003. Indek aktivitas antioksidan ekstrak rumput laut coklat (Sargassum aquifolium). Jurnal Pengolahan Hasil Perikanan Indonesia. 16(1): 42-47

Gazali, M., Nurjanah, Zamani, N.P. 2018. Eksplorasi senyawa bioaktif alga cokelat Sargassum sp. Agardh sebagai antioksidan dari Pesisir Barat Aceh. Jurnal Pengolahan Hasil Perikanan Indonesia. 21(1):167-178.

Goodwin, T.W. 1976. Chemistry and Biochemistry of Plant Pigments. Academic Press, New York.

Haryatfrehni, R., Dewi, S.C, Meilianda, A., Rahmawati, S., Sari, I.Z.R. 2015. Preliminary study the potency of macroalgae in Yogyakarta: extraction and analysis of algal pigments from common Gunungkidul seaweeds. Procedia Chemistry. 14: 373-380.

Holdt, S.L., Kraan, S. 2011. Bioactive compounds in seaweed: Functional food applications and legislation. Journal of Applied Phycology. 23: 543-597.

Krinsky NI. 1968. Photophysiology III. Academic Press, New York.

Leibo, R.D.M.H., Mantiri, G.S., Gerung. 2016. Uji aktivitas antioksidan dari ekstrak total alga hijau Halimeda opuntia Linnaeus dan Halimeda macroloba Decaisne dari perairan teluk totok. Jurnal Pesisir dan Laut Tropis. 2(1):36.

Machu, L., Misurcova, L., Ambrozova, J.V., Orsavova, J., Mlcek, J., Sochor, J., Jurikova, T. 2015. Phenolic content and antioxidant capacity in algal food products. Molecules. 20(1): 1118-1133.

Macpherson, Hiller. 2003. Light-Harvesting Systems in Chlorophyll C-Containing Algae. Green BR, Parson WW, editors. Light-Harvesting Antennas in 
Photosynthesis. Kluwer; Dordrecht, pp. 323-352.

Neilson, J.A.D., Durnford, D.G. 2010. Structural and functional diversification of the lightharvesting complexes in photosynthetic eukaryotes. Photosynth Res. 106: 57-71.

Nufus, C., Nurjanah, Abdullah, A.. 2017. Karakteristikrumput laut hijau dari perairan Kepulauan Seribu dan Sekotong Nusa Tenggara Barat sebagai antioksidan. Jurnal Pengolahan Hasil Perikanan Indonesia. 20(3): 620-630.

Pangestuti, R., Kim, S.K. 2011. Biological activities and health benefit effects of natural pigments derived from marine algae. Journal of Functional Foods. 3: 255266.

Prangdimurti, E., Muchtadi, D., Astawan, M., Zakaria, F.R. 2006. Aktivitas antioksidan ekstrak daun suji (Pleomele angustifolia NE Brown). Jurnal Teknologi dan Industri Pangan. 17(2): 79-85.

Rohani-Ghadikolaei, K., Abdulalian, E., Ng, W.K. 2012. Evaluation of the proximate, fatty acid and mineral composition of representative green, brown and red seaweeds from the Persian Gulf of Iran as potential food and feed resources. Journal of Food Science and Technology. 49(6): 774-780.

Subaryono, Perangiangin, R., Suhartono, M.T., Zakaria, F.R. 2017. Aktivitas imunomodulator oligosakarida alginat (OSA) yang dihasilkan dari alginat asal Sargassum crassifolium. Jurnal Pengolahan Hasil Perikanan Indonesia. 20(1): 63-73.

Zakaria, F.R., Priosoeryanto, B.P., Erniati, Sajida. 2017. Karakteristik nori dari campuran rumput laut Ulva lactuca dan Eucheuma cottoni. Jurnal Pascapanen dan
Bioteknologi Kelautan dan Perikanan. 12(1):23-30. 